\title{
Nutrient intake of cattle on rotational and continuous graz- ing treatments
}

\author{
C. DAVID MCKOWN, JOHN W, WALKER, JERRY W. STUTH, AND RODNEY K. HEITSCHMIDT
}

\begin{abstract}
Many benefits have been obtained from rotational grazing, including management flexibility and livestock distribution, but long-term positive effects on plant and animal production have been inconsistent. The purpose of this case study was to investigate nutrient intake of animals in 2 production scale grazing treatments. The study site was the Texas Experimental Ranch located in Throckmorton County, in the eastern portion of the Rolling Plains of Texas. Treatments were a 465-ha, 16-paddock, 1-herd, cell designed rotational grazing system (RG) stocked at a heavy rate $\left(3.7 \mathrm{ha} \cdot \mathrm{cow}^{-1} \bullet \mathrm{yr}^{-1}\right.$ ) and a 248-ha continuously grazed (CG) treatment stocked at a moderate rate $\left(6.2 \mathrm{ha}^{\circ} \operatorname{cow}^{-1} \bullet \mathrm{yr}^{-1}\right)$. Size of RG paddocks was varied to create different livestock densities to simulate rotational grazing at $a 14$ and 42 paddock level. Comparisons were made to determine the effect of type of grazing system (RG vs. CG) and the effect of livestock density within the RG system on nutrient intake. Nutrient intake of esophageally fistulated steers was determined by daily dosing them with ytterbium nitrate-labeled forage and collection of fecal samples plus collection of fistula extrusa samples for crude protein and in vitro organic matter digestibility determinations. The only difference caused by different livestock densities was a higher $(P<0.001)$ intake of forage crude protein in the simulated 42 paddock system. Nutrient intake of steers in the CG treatment was greater $(P<0.001)$ than those in the RG treatment. Differences between treatment were attributed primarily to differences in stocking rate rather than grazing system.
\end{abstract}

Key Words: grazing system, livestock density, fecal output, ytterbium

Authors are resident manager, Texas Agricultural Experiment Station, La Copita Research Area, Alice, Texas 78333; range scientist, USDA-ARS Sheep Experiment Station. HC 62, Box 2010, Dubois, Ida. 83423; professor, Department of Range Science, Texas A\&M University, College Station 77843; location leader, Livestock and Range Research Station, Route 1, Box 2021, Miles City, Mont. 59301.

Appreciation is extended to the Swen R. Swenson Cattle Co. for providing the land, livestock, and facilities for this study and the Texas Experiment Ranch Committee for providing financial assistance.

Report is published with the approval of the Director, Texas Agr. Exp. Sta. as TA-25064.

Manuscript accepted 11 April 1991.
Nutrient intake is regulated by an animal's nutrient requirements, the quantity and quality of feedstuff available, and the animal's inherent ability to harvest nutrients within an energy, time, and bulk constrained environment (Westoby 1974, Ellis et al. 1976, Allison 1985). A major impetus for employing various grazing management strategies on rangelands is to manipulate factors affecting nutrient intake positively to enhance individual animal production and/or production per unit area. A major objective of multi-paddock, single herd rotational grazing strategies (RG) is to increase livestock production per unit area by increasing efficiency of harvest while maintaining nutrient intake and individual animal performance.

The objective of this study was to compare the nutrient intake of cattle on a heavily stocked $R G$ treatment that contained 2 stocking densities, with a moderately stocked continuously grazed treatment (CG). The specific null hypothesis was that nutrient intake would be equal for the 2 treatments regardless of stock density (number of paddocks) in the RG treatment. This study was one of a series of studies designed to quantify the effects of the RG treatment on quantity and quality of forage produced (Heitschmidt et al. 1987a, 1987b, 1987c), diet quality (Walker et al. 1989b), cow/ calf production and economic returns (Heitschmidt et al. 1990), watershed condition (Pluhar et al. 1987), number of cattle trails (Walker and Heitschmidt 1986), and several livestock behavioral attributes (Walker and Heitschmidt 1989, Walker et al. 1989a).

\section{Methods}

\section{Study Site}

The study site was the Texas Experimental Ranch located in Throckmorton County, in the eastern portion of the Rolling Plains of Texas $\left(99^{\circ} 14^{\prime} \mathrm{W}, 33^{\circ} 20 \mathrm{~N}\right)$. Climate is continental and semiarid. Average annual precipitation is $680 \mathrm{~mm}$ bimodally distributed with peaks in May and September. Average maximum daily temperatures range from $11.4^{\circ} \mathrm{C}$ in January to $35.8^{\circ} \mathrm{C}$ in July. Average minimum daily temperatures range from $-2.4^{\circ} \mathrm{C}$ in January to $22.0^{\circ} \mathrm{C}$ in July.

Soils on the study site are generally deep, well drained, clays and 
Table 1. Duration and sequence of nutritive intake trials. The length of the rest period was a function of the estimated growth rate of forage. During dormancy rest periods were about 60 days and during rapid growth rest periods were about 30 days. Graze periods were a function of the rest period, number and size of paddocks in the grazing system.

\begin{tabular}{|c|c|c|c|c|c|c|c|c|}
\hline & \multicolumn{8}{|c|}{ Trial dates } \\
\hline & \multirow{2}{*}{$\frac{1982}{\text { Oct. }}$} & \multicolumn{3}{|c|}{1983} & \multicolumn{4}{|c|}{1984} \\
\hline & & Jan. & June & Sep. & Jan. & Mar. & May & Aug. \\
\hline & \multicolumn{8}{|c|}{ days } \\
\hline $\begin{array}{l}\text { Length of Graze } \\
\text { RG-14 } \\
\text { RG-42 } \\
\text { Length of rest } \\
\text { Length of trial }\end{array}$ & $\begin{array}{r}3 \\
1 \\
45 \\
9\end{array}$ & $\begin{array}{l}4 \\
1.3 \\
60 \\
12\end{array}$ & $\begin{array}{c}2 \\
0.6 \\
30 \\
6\end{array}$ & $\begin{array}{r}3 \\
1 \\
45 \\
9\end{array}$ & $\begin{array}{r}4 \\
2 \\
65 \\
15\end{array}$ & $\begin{array}{r}3 \\
1 \\
45 \\
9\end{array}$ & $\begin{array}{c}2 \\
0.6 \\
30 \\
6\end{array}$ & $\begin{array}{r}3 \\
1 \\
45 \\
9\end{array}$ \\
\hline
\end{tabular}

clay loams, with the clay loams predominating. Herbaceous vegetation is a mixture of short- and midgrasses. Dominant shortgrasses are buffalograss [ Buchloe dactyloides (Nutt.) Engeim.] and common curlymesquite [Hilaria belangeri (Steud.) Nash], both warm-season perennials. Dominant midgrasses are sideoats grama [Bouteloua curtipendula (Michx.) Torr.], a warm-season perennial, and Texas wintergrass (Stipa leucotricha Trin. and Rupr.), a cool-season perennial. The dominant annual grass is Japanese brome (Bromus japonicus Thumb.). The dominant woody species is honey mesquite (Prosopis glandulosa Torr. var. glandulosa). For a detailed description of the climate, soils, range sites, and vegetation at the study site, see Heitschmidt et al. (1985).

\section{Treatments}

Treatments consisted of a 465-ha, cell designed RG treatment, established in March 1981, and a single 248-ha pasture CG treatment, established in 1960 . Both treatments were stocked with mature Hereford $X$ Angus crossbred cows and all treatment pastures had a range condition classification of good throughout the study. Rate of stocking in the RG treatment was 3.7 ha $\bullet$ cow $^{-1} \bullet \mathrm{yr}^{-}$ ${ }^{1}$ until June 1984 when the stocking rate was reduced to $5.2 \mathrm{ha} \cdot \mathrm{cow}^{-1}$ - $\mathrm{yr}^{-1}$ because of drought. Stocking rate for the $\mathrm{CG}$ treatment was a constant $6.2 \mathrm{ha} \cdot \mathrm{cow}^{-1} \cdot \mathrm{yr}^{-1}$.

The stocking rate used in the RG treatment was chosen for 2 reasons: (1) previous studies (Heitschmidt et al. 1983) showed that stocking at $3.7 \mathrm{ha} \bullet \mathrm{cow}^{-1} \bullet \mathrm{yr}^{-1}$ exceeded the carrying capacity of this range under continuous grazing, and (2) one of major reasons for implementing a short duration grazing system was to increase carrying capacity (Savory and Parsons 1980). Continuous grazing at $6.2 \mathrm{ha} \bullet \mathrm{cow}^{-1} \bullet \mathrm{yr}^{-1}$ was chosen as the control treatment to compare the RG treatment to because it is the recommended stocking rate (Kothmann et al. 1970, Heitschmidt et al. 1982) for continuous grazing at this location and continuous grazing is the most common grazing system in this area.

The RG treatment initially consisted of 14 paddocks that averaged 33 ha in size. In March 1982 one 30-ha paddock was subdivided into three 10-ha paddocks. Data for this study were collected in these three 10-ha paddocks and 2 adjacent 30-ha paddocks. To maintain equal rates of stocking, the length of each grazing period was adjusted by an amount proportional to pasture size. Length of graze in the flexible rotation schedule ranged from 2 to 5 days in the 30-ha paddocks and 18 hours to 2 days in the 10-ha paddocks. Length of rest between grazing periods ranged from approximately 30 to 65 days. The 30-ha paddocks are referred to hereafter as the RG-14 treatment and the 10-ha paddocks are referred to hereafter as the RG-42 treatment because livestock density in the RG-14 and RG -42 paddocks approximate that in a 14- and 42-paddock RG system, respectively. For a more detailed description of the treatments, see Heitschmidt et al. (1987a, 1987c, 1990).

\section{Sampling Procedures}

Eight nutritive intake trials were conducted from October 1982 to August 1984 (Table 1). Each trial was conducted as the cattle entered the RG treatment paddocks in their normal rotation cycle. Ten esophageal-fistulated steers were used for both fecal output and diet quality sampling during the first 4 trials. Four intact steers were used to obtain additional estimates of fecal production, for the last 4 trials. They were equally allocated between the 2 treatments. Steers were assigned randomly to treatments for trial 1 and alternated between treatments for each successive trial. Number of steers allocated to treatments varied across trials because of health disorders. Five fistulated steers were always allocated to the RG treatment and the remaining 3 or 4 were used in the CG treatment. This method of distributing animals among treatments was used because conditions in the CG treatment were assumed to remain constant during a trial and the greater number of sample dates was assumed to offset the fewer numbers of animals. The minimal number of animals for any trial was 3 in the CG and 4 in the RG treatments. Steers were pastured with the main cow herds from 1 week before a trial until the end of each trial.

In the RG treatments, diet samples were collected in all paddocks at the beginning and end of each grazing period. An additional mid-grazing period sample was collected in the RG-14 paddocks. In the CG treatment diet collections were taken every other day throughout the trial. Diet collections were made without fasting while the main cow herd was in a major feeding period. Steers, were gathered, fitted with screen-bottomed bags, and returned to graze in the same area as the main cow herd. Extrusa samples were frozen at $-15^{\circ} \mathrm{C}$ and later freeze-dried and ground. They were composited by pasture and date before being analyzed for in vitro digestible organic matter (IVDOM) and crude protein. Percent IVDOM was estimated by a 2-stage procedure for incubating the sample in strained rumen fluid for $\mathbf{4 8}$ hours, followed by neutral detergent extraction (Van Soest et al. 1987). Estimates of IVDOM were corrected using the ratio of in vitro/in vivo digestibility of standard forages of known digestibility determined in a feeding trial. The standard forage was pre-bloom oat hay that had in vitro and in vivo digestible organic matter of 58 and $65 \%$, respectively. Percent nitrogen, on an organic matter basis, was determined by the micro-Kjeldahl method (AOAC 1970) and converted to crude protein using a factor of 6.25 . A complete description of the diet quality study can be found in Walker et al. (1989b).

Fecal output was estimated using ytterbium nitrate, an indigestible particulate flow marker, in a daily dosing technique (Ellis et al. 1982). Rice hulls were used as a carrier for the ytterbium (Yb), which was administered at the rate of $1.5 \mathrm{~g}$ of ytterbium nitrate per $100 \mathrm{~kg}$ of body weight. Samples of the marked rice hulls were used to determine actual $\mathrm{Yb}$ concentration per dose for each trial. Pretrial dosing was done for 4 days. The steers were gathered each morning, before the main herd's major feeding period, dosed, and 

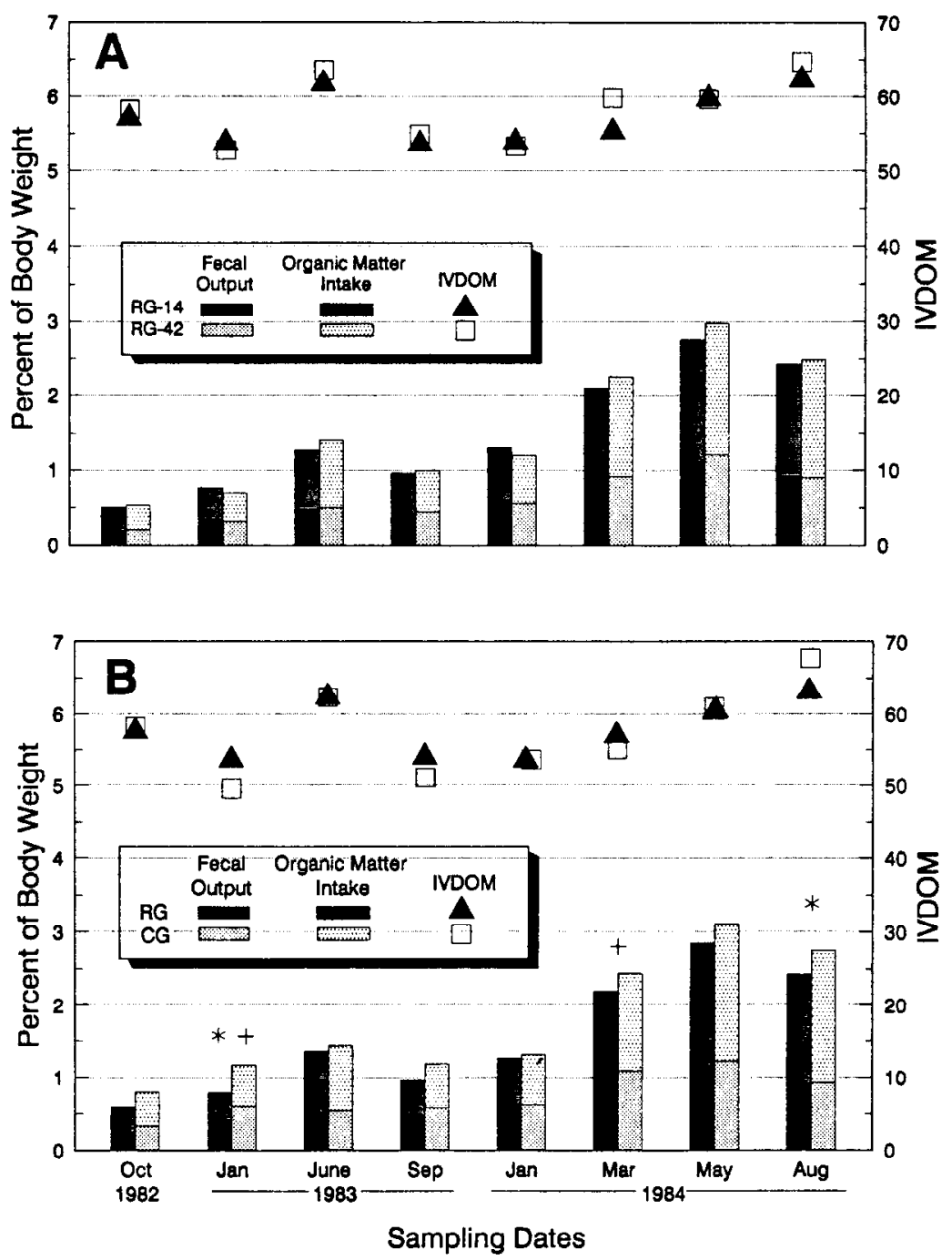

Fig. 1. The affect of livestock density in a rotational grazing treatment (A) or type of grazing treatment (B) on fecal organic matter output (\% of body weight), organic matter intake (\% of body weight) and diet in vitro digestible organic matter (IVDOM) on 8 sample dates. Dates with asterisks (") or plus $(+)$ above them indicate that treatment means are different $(P<0.05)$ for OMI and FOMOUT, respectively.

fecal samples collected. Dose and collection times were selected to minimize diurnal variation (Prigge et al. 1981). Fecal samples were dried at $60^{\circ} \mathrm{C}$ for 48 hours and ground in a Wiley mill to pass a 2-mm screen. Fecal dry matter, organic matter (AOAC 1970), and ytterbium concentrations were then determined. Ytterbium-labeled rice hull and fecal samples were prepared for analysis by solubilizing a 1-g ash sample in 1 normal hydrochloric/nitric acid (Ellis et al. 1982). After filtration and dilution, Yb was determined by atomic absorption spectroscopy using a nitrous oxide/acetylene flame. Ytterbium standards ( 0 to $5 \mathrm{ppm})$ were made from pretrial fecal collections that contained no $\mathrm{Yb}$.

\section{Calculations and Statistical Analyses}

Daily fecal organic matter output (FOMOUT) was calculated by dividing the actual dose of $\mathrm{Yb}(\mu \mathrm{g} /$ day) by $\mathrm{Yb}$ concentration in the fecal organic matter $(\mu \mathrm{g} / \mathrm{g})$. Organic matter intake (OMI) was calculated by dividing FOMOUT by the indigestible (100-IVDOM) fraction of the diet. Fecal organic matter output and OMI were expressed as a percent of body weight.

Forage crude protein intake (FCPI) was derived by multiplying the average percent CP of diets (Walker et al. 1989b), times the kg of OMI. Forage metabolizable energy (ME) intake (FMEI), expressed as $\mathrm{Mcal} \bullet \mathrm{hd}^{-1} \bullet \mathrm{day}^{-1}$, was calculated by multiplying $\mathrm{ME}$ concentration (Mcal/ $\mathrm{kg}$ ) in the extrusa by $\mathrm{kg}$ OMI. Extrusa DE concentration was calculated using the formula of Rittenhouse et al. (1971) to estimate digestible energy (DE) from IVDOM (i.e., Mcal DE $/ \mathrm{kg}=\mathrm{IVDOM} \bullet 0.05-0.36)$. Digestible energy was converted to ME assuming an $80 \%$ conversion efficiency $\left(\mathrm{k}_{\mathrm{m}}\right)$ of DE to ME. Requirements for FCPI and FMEI were calculated for each trial based on NRC (1984) recommendations for medium frame steers of similar weight and average daily gain as the animals used in this study. Within a trial, daily values of the dependent variables FOMOUT, OMI, FCPI, and FMEI were averaged for each steer. For steers in the RG treatment daily values were averaged separately for the days when the animals were in the RG-14 and RG-42 paddocks to test the effect of livestock density. Data for each steer were averaged across all days and paddocks in the RG treatment to test for the effect of RG compared to $C G$. These data were analyzed for the effect of grazing treatment, trial and their interaction with steer weight as a covariate. Mean separations were based on single degree of freedom contrast. Individual animals were used as experimental units but were not independent and any inferences made from this grazing treatment case study to a larger population are based on the authors' experience and supporting literature. 

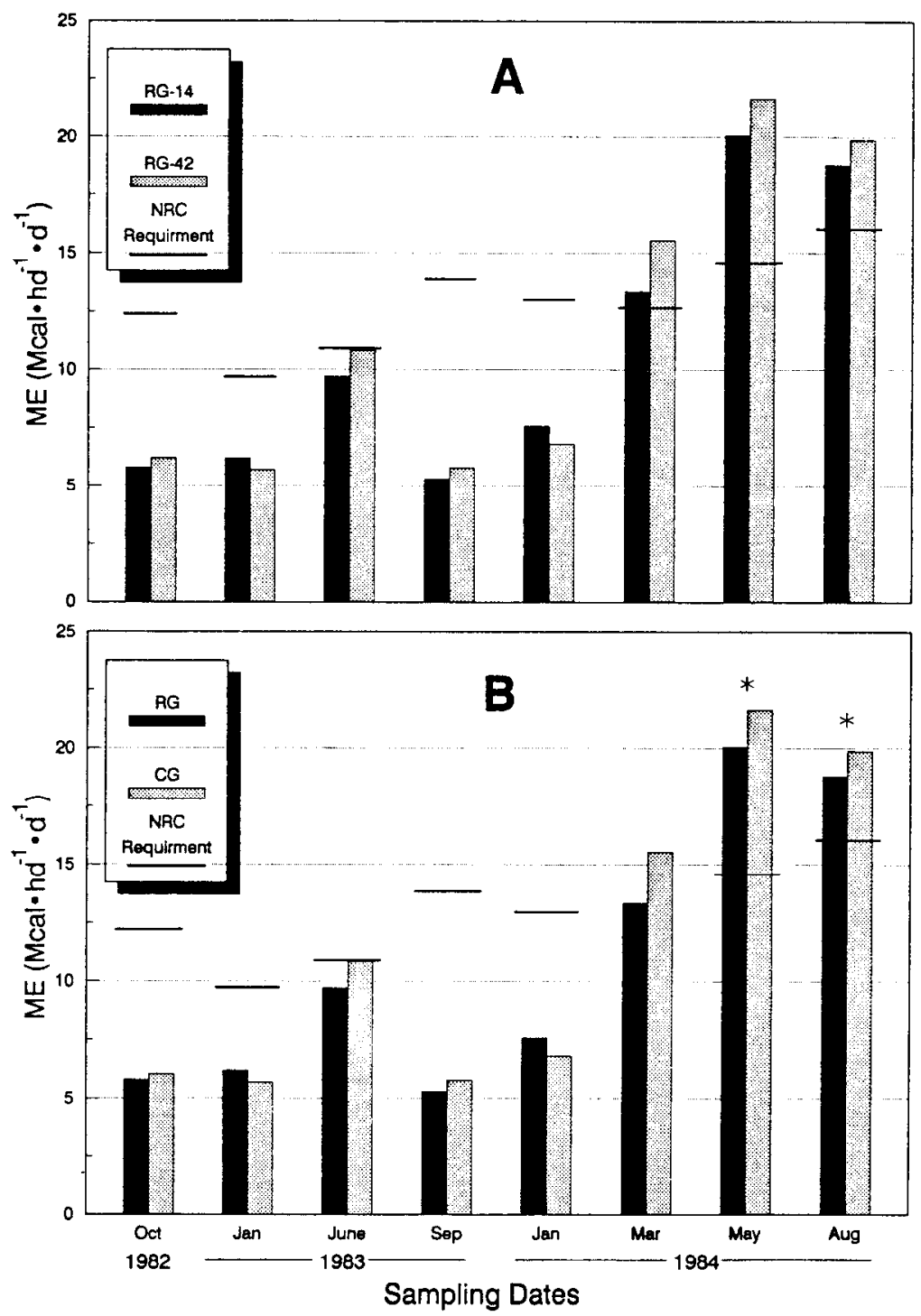

Fig. 2. The affect of livestock density in a rotational grazing treatment (A) or type of grazing treatment (B) on forage metabolizable energy intake on 8 sample dates. Requirements were calculated for each trial using the weight and average daily gain of the stecrs used to collect nutrient intake data and NRC (1984) recommendations for medium frame steers.

\section{Results}

Trial

All response (FOMOUT, OMI, FCPI, and FMEI) variables differed $(P<0.01)$ between trials because of the seasonal effects on forage quantity and quality. In general OMI increased as IVDOM increased. There was also an increase in all response variables during the last 3 trials; however, the cause of this increase was not apparent.

\section{RG-14 vs. RG-42}

FOMOUT, OMI, and FMEI were not affected $(P<0.98,0.36$, and 0.09 , respectively) by the main effect of stock density within the RG treatment (i.e., RG-14 vs. RG-42; Figs. $1 \mathrm{~A}$ and $2 \mathrm{~A}$ ). FCPI was greater $(P<0.001)$ in the RG-42 than the RG-14 treatment and the treatment $\times$ trial interaction was also significant (Fig. 3A). The greater FCPI by the steers on the RG-42 treatment compared to steers on the RG-14 treatment was primarily caused by the higher crude protein content of their diets 9.4 vs. $8.6 \%$, respectively averaged across the 8 trials (Walker et al. 1989b). The interaction occurred because FCPI was only greater in the RG-42 compared to
RG-14 treatments $(\boldsymbol{P}<0.01)$ during the spring and summer trials (i.e., June 1983, March, May, and August 1984) when forage quality was high. The data from the RG-14 and RG-42 treatments were combined into a single RG treatment for further analyses.

\section{RG vs. CG}

All variables examined (FOMOUT, OMI, FCPI, and FMEI) were greater $(P<0.001)$ for steers in the $C G$ than $R G$ treatment when averaged across dates. FCPI was the only variable that was affected $(P<0.001)$ by the interaction of date and grazing treatment. Averaged across dates FOMOUT was 0.6 and $0.7 \%$ of body weight in the RG and CG treatments, respectively (Fig. 1B). Within a date FOMOUT only differed $(P<0.02)$ between treatments during the January 1983 and March 1984 trials. Averaged across dates OMI was 1.5 and $1.8 \%$ of body weight in the RG and CG treatments, respectively (Fig. 1B). Within a date OMI only differed $(P<0.04)$ between treatments during the January 1983 and August 1984 trials. FMEI and FCPI followed similar patterns differing $(P<0.01)$ only in May and August 1984 when compared within a trial (Figs. 2B and 3B, respectively). A date $\times$ treatment interaction for FCPI was caused by the large difference between treatments at 

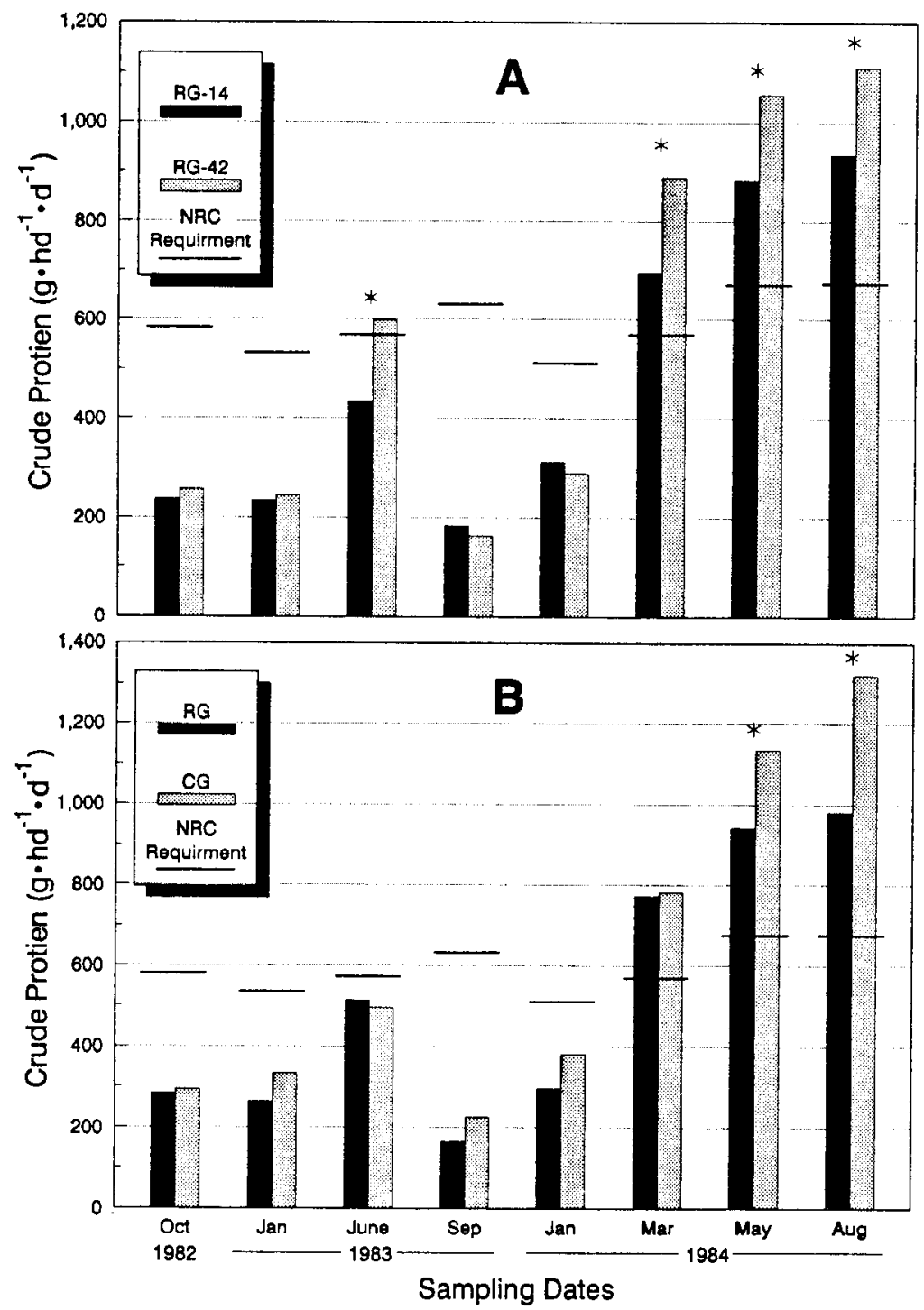

Fig. 3. The affect of livestock density in a rotational grazing treatment (A) or type of grazing treatment (B) on forage crude protein intake on 8 sample dates. Requirements were calculated for each trial using the weight and average daily gain of the steers used to collect nutrient intake data and $\mathrm{NRC}$ (1984) recommendations for medium frame steers. Dates with asterisks $\left({ }^{*}\right)$ above them indicate that treatment means are different $(P<0.05)$.

the last 2 dates compared to rather similar levels during the previous trials.

\section{Discussion and Conclusions}

The results from this study show that increasing the number of paddocks from 14 to 42 did not enhance nutrient intake. The similarity in forage intake at different livestock densities in the RG treatment (i.e., RG-14 vs. RG-42) agree with previous studies that showed quantity (Heitschmidt et al. 1987a) and quality (Heitschmidt et al. 1987b) of forage, and the quality of diets (Walker et al. 1989b) were also similar between these 2 treatments.

Differences in OMI between the RG and CG treatments appeared to be caused by differences in FOMOUT and/or diet IVDOM that in turn were related to the quantity and quality of available forage. In January 1983 the CG treatment had greater FOMOUT that resulted in higher intake despite lower dietary IVDOM (Fig. 1B). During this trial total herbage standing crop was twice as high in the CG compared to the RG treatment (2100 vs. $1,000 \mathrm{~kg} \cdot \mathrm{ha}^{-1}$ ) (Heitschmidt et al. 1987c). On the other occasion when FOMOUT was significantly greater in the CG compared to RG treatment (i.e., March 1984) herbage standing crop was again almost twice as high in the CG compared to RG treatment ( $1400 \mathrm{vs.}$ $700 \mathrm{~kg} \bullet \mathrm{ha}^{-1}$ ). Higher OMI during the August 1984 trial was caused by higher dietary IVDOM in the CG compared to RG treatments. During this trial FOMOUT and total herbage standing crop (Heitschmidt et al. 1987c) were similar between treatments. These data suggest that if differences in forage intake are caused by low forage availability, they will be reflected in a reduction in FOMOUT.

Estimated intakes of ME and CP did not meet NRC (1984) recommendation except for the last 3 trials. Walker et al. (1989c) found that for these data to be used to simulate livestock performance, estimates of both FOMOUT and IVDOM had to be increased. Thus FOMOUT and/or IVDOM were probably under estimated in the first 5 trials.

The results from this and companion studies conducted between 1982 and 1987 provide information explaining why individual animal performance in the RG treatment was consistently less than in the CG treatment. During this period, Heitschmidt et al. (1990) reported that calf weaning weights averaged 260 and $249 \mathrm{~kg}$ in the 
CG and RG treatments, respectively. The results from this study suggest the reduced performance in the RG treatment was at least a partial result of limited nutrient intake. These limitations appeared to be related primarily to restrictions imposed at various times because of limited amounts of available forage (Heitschmidt et al. 1987c) instead of limitations resulting from reduced diet quality (Walker et al. 1989b). The current findings support those of others who have shown that as forage availability or herbage allowance decreases, nutrient intake (Greenhalgh et al. 1966, Allison and Kothmann 1979, Baker et al. 1981, Parsons et al. 1983) and livestock performance (Hart 1972) also decline regardless of grazing strategy (Olson 1984, Ralphs et al. 1986, Hart et al. 1988). However, when using these same data to simulate animal performance with a deterministic model, Walker et al. (1989c) found that simulated treatment differences in calf weights were greater than actual differences. They suggested that greater frequency of diet sampling by steers in the RG relative to CG treatment may have resulted in an underestimation of FOMOUT by the steers in the RG treatment.

Finally, it should be emphasized that the results from this study do not provide evidence that forage nutrient intake in a properly stocked RG treatment would be different from that in any other properly stocked grazing treatment. The results simply imply that forage nutrient intake will periodically be less in heavily stocked than moderately stocked, yearlong grazing treatments.

\section{Literature Cited}

Allison, C.D. 1985. Factors affecting forage intake by range ruminants: A review. J. Range Manage. 38:305-311.

Allison, C.D., and M.M. Kothmann. 1979. Effect of level of stocking pressure on forage intake and diet quality of range cattle. Proc. West. Section, Amer. Soc. Anim. Sci. 30:174-178.

AOAC. 1970. Official methods of analysis (11th Ed.). Assoc. Offic. Analyt. Chem. Washington, D.C.

Baker, R.D., F. Alvaren, and Y.L.P. Le Du. 1981. The effect of herbage allowance upon the herbage intake and performance of suckler cows and calves. Grass and Forage Sci. 36:189-199.

Ellis, J.E., J.A. Wiens, C.F. Rodell, and J.C. Anway. 1976. A conceptual model of diet selection as an ecosystem process. J. Theor. Biol. 60:93-108.

Ellis, W.C., C. Lascano. R. Teeter, and F.N. Owens. 1982. Solute and particulate flow markers. p. 37-57. In: Protein requirements for cattle. Oklahoma State Univ. MP-109.

Greenhalgh, J.F.D., G.W. Reid, J.N. Aitken, and E. Florence. 1986. The effects of grazing intensity on herbage consumption and animal production. I. Short-term effects in strip-grazed dairy cows. J. Agr. Sci. 67:13-23.

Hart, R.H. 1972. Forage yield, stocking rate and beef gains on pasture. Herb. Abstr. 42:345-353.

Hart, R.H., M.J. Samuel, P.S. Test, and M.A. Smith. 1988. Cattle, vegetation, and economic responses to grazing systems and grazing pressure. $J$. Range Manage. 41:282-286.

Heitschmidt, R.K., J.R. Conner, S.K. Canon, W.E. Pinchak, J.W. Walker, and S.L. Dowhower. 1990. Cow/calf production and economic returns from yearlong continuous, deferred rotation and rotational grazing treatments. J. Prod. Agr. 3:92-99.

Heitschmidt, R.K., S.L. Dowhower, R.A. Gordon, and D.L. Price. 1985. Response of vegetation to livestock grazing at the Texas Experimental Ranch. Texas Agr. Exp. Sta. B-1515.
Heitschmidt, R.K., S.L. Dowhower, and J.W. Walker. 1987a. 14- vs. 42-paddock rotational grazing: Aboveground biomass dynamics, forage production, and harvest efficiency. J. Range Manage. 40:216-223.

Heitschmidt, R.K., S.L. Dowhower, and J.W. Walker. 1987b. 14- vs. 42-paddock rotational grazing: Forage quality. J. Range Manage. 40:315-317.

Heitschmidt, R.K., S.L. Dowhower, and J.W. Walker. 1987c. Some effects of a rotational grazing treatment on quantity and quality of available forage and amount of ground litter. J. Range Manage. 40:318-321.

Heitschmidt, R.K., A.B. Johnson, J.R. Frasure, and D.L. Price. 1983. Cow-calf and vegetation response to heavy rates of stocking at the Texas Experimental Ranch. Texas Agr. Exp. Sta. Bull. 1427.

Heitschmidt, R.K., M.M. Kothmann, and W.J. Rawlins. 1982. Cow-calf response to stocking rates, grazing systems and winter supplementation at the Texas Experimental Ranch. J. Range Manage. 35:204-210.

Kothmann, M.M., G.W. Mathis, P.T. Marion, and W.J. Waldrip. 1970. Livestock production and economic returns from grazing treatments on the Texas Experimental Ranch. Texas Agr. Exp. Sta. Bull. 1100.

NRC. 1984. Nutrient requirements of beef cattle (6th Rev. Ed.). National Academy Press, Washington, D.C.

Olson, P.D. 1984. Influence of stocking rate on nutritive intake of steers grazing a short duration grazing system. Ph.D. Diss. Texas A\&M Univ., College Station.

Parsons, A.J., E.L. Leafe, B. Collett, P.D. Penning, and J. Lewis. 1983. The physiology of grass production under grazing. II. Photosynthesis, crop growth and animal intake of continuous grazed sward. J. Appl. Ecol. 10:127-139.

Pluhar, J.J., R.W. Knight, and R.K. Heitschmidt. 1987. Infiltration rates and sediment production as influenced by grazing systems in the Texas Rolling Plains. J. Range Manage. 40:240-243.

Prigge, E.C., G.A. Varga, J.L. Vicinl, and R.L. Reid. 1981. Comparison of ytterbium chloride and chromium sesquioxide as fecal indicators. $J$. Anim. Sci. 53:1629-1633.

Ralphs, M.H., M.M. Kothmann, and L.B. Merrill. 1986. Cattle and sheep diets under short-duration grazing. J. Range Manage. 39:217-223.

Rittenhouse, L.R., C.L. Streeter, and D.C. Clanton. 1971. Estimating digestible energy from digestible dry and organic matter in diets of grazing cattle. J. Range Manage. 24:73-75.

Savory, A., and S.D. Parsons. 1980. The Savory grazing method. Rangelands 2:234-237.

Van Soest, P.J., R.H. Wine, and L.A. Moore. 1987. Estimation of the true digestibility of forage by the in vitro digestion of cell walls. Proc. 10th Int. Grassl. Congr. 10:438-441.

Walker, J.W., and R.K. Heitschmidt. 1986. Effect of various grazing systems on type and density of cattle trails. J. Range Manage. 39:428-431.

Walker, J.W., and R.K. Heitschmidt. 1989. Some effects of a rotational grazing treatment on cattle grazing behavior. J. Range Manage. 42:337-342.

Walker, J.W., R.K. Heitschmidt, and S.L. Dowhower. 1989a. Some effects of a rotational grazing treatment on cattle preference for plant communities. J. Range Manage. 42:143-148.

Walker, J.W., R.K. Heitschmidt, E.A. de Moreses, M.M. Kothmann, and S.L. Dowhower. 1989b. Quality and botanical composition of cattle diets under rotational and continuous grazing treatments. J. Range Manage. 42:239-242.

Walker, J.W., J.W. Stuth, and R.K. Heitschmidt. 1989c. A simulation approach for evaluating field data from grazing trials. Agr. Syst. 30:301-316.

Westoby, M. 1974. An analysis of diet selection by large generalist herbivores. Amer. Natur. 108:290-304. 